\title{
SOME SOUTHERN ALBERTA ANIMALS - 1974
}

\author{
by WAYNE W. SMITH*
}

While engaged in biological research during the spring and summer of 1974, observations of some interest to naturalists were made. Most of the observations come from the Lost and Milk Rivers in and near the Pinhorn Grazing Preserve of extreme southern Alberta. Other observations came from the Middle Sand Hills (Empress area), Hand Hills (northeast of Drumheller) and the Waterton Lakes National Park area.

\section{BIRDS}

RED-NECKED GREBE: One pair with a nest containing (at least) several eggs was found in a roadside pond near Mountain View (June.11). This area is on the eastern edge of the front range of the Rocky Mountains near Waterton Lakes National Park. Red-necked Grebes have only seldomly been reported as nesting in the foothills and mountains.

FERruginous HaWk: Despite intensive field work, only one active eyrie was found in the Lost River-Milk River area. Numerous old and deserted eyries were found, e.g., $40+$ in several miles of one large coulee. It appears that the scarcity of these birds is correlated with the apparent absence of ground squirrels in the area. It is interesting to note that the one occupied eyrie was close to the cultivated fields of northern Montana and contained the remains of the only ground squirrel seen in the Pinhorn.

GOLDEN EAGLE: In contrast to Ferruginous Hawks, Golden Eagles

* 8220 Elbow Drive

Calgary, Alberta. were comparatively common. Four tive eyries were found in coul leading into the Milk River. $E_{c}$ eyrie contained either one or $t$ young towards the end of the fledgl period. This indicates a fair reprod tive success. Each eyrie was built o relatively inaccessible cliff with a on manding view. It appears that staple food item was Cottontail Rab which were common.

MERLIN: Three Merlin eyries were fol in 5 square miles of aspen grovelane the Hand Hills near Little Fish La This seems to be a relatively de e population for a raptor species wh $\mathrm{e}$ population has declined drasticall $n$ the last little while. Each of the $t h$ e eyries contained at least 3 young one contained 5 young. It appears the high passerine population of area may be one factor explaining relatively high density of Merlins.

PIPING Plover: One pair was pres it through the summer on the west en Little Fish Lake. Although no nest found, nesting was definitely dicated.

BLACK-BILLED CUCKOO: This seldom bird appeared to be quite common small stretch of the lower Red I River near Empress. At least $3 \mathrm{~m}$ es were observed during the summer, id one immature was noted in mid-J y One male was also heard in the $\mathrm{F}$ id Hills on July 11.

BURROWING OWL: Despite intensive ching of vast tracts of grassland, or pairs of Burrowing Owls were during the summer. Both pairs we: in the Middle Sandhills region ar Hilda. Both pairs were apparently ccupying nesting holes.

WILLOW FLYCATCHER: One male was ol $r$ ved, apparently occupying a terr in a dense willow-rose tangle alo 
small creek heading into the north end if Little Fish Lake. This was on June 19. Several weeks later there was no sign of this individual.

Jiolet-green sWallow: One nest was found June 10 in a steep coulee leading into the Milk River. The presence of several more pairs in other coulees seems to indicate a thinly distributed nesting population hroughout suitable areas of the Milk River valley. This population may derive from birds following the Milk River downstream from its source in he Montana Rocky Mountains; or may result from a nesting population in the nearby Sweetgrass Hills of Montana.

BLACK-THROATED GREEN WARBLER: Three ringing males were found June 16 in Waterton Lakes National Park. They appeared to be on territory. This species is seldom found in the mounains, but is apparently a scarce summer resident in Waterton (park checklist of birds).

NORTHERN ORIOLE: Fairly large numbers were found in the cottonwood stands of the Milk River valley. This hopulation appeared to be equally divided between the Baltimore and Bullock's forms. Also, numerous hybrids covering a wide spectrum of characteristics between the parent forms were observed.

black-HeAded GRosbeaK: Several males were observed along a river valley in Waterton Lakes National Park during June. Several males were also observed in cottonwood stands in the Milk River valley during the summer.

GRASSHOPPER SPARROW: This species was ound to be quite common in some ireas of the Middle Sandhills. Areas where they were found ranged from near Empress to near Hilda. It appears hat this species was associated entirely with the rolling sandhills vegetation of his area.

\section{MAMMALS}

VELLOW-BelLied Marmot: Only one was observed in a coulee leading into the Milk River on May 3. Other areas of uitable rocky outcrops apparently contained no Marmots. It may be that the population is still too thin to occupy all available habitat.

BUSHY-TAILED WOod rat: Active dens were noted throughout badland sections of the Lost and Milk Rivers.

THIRTEEN-LINED GROUND SQUIRREL: One was observed at Del Bonita (SW Alberta) June 12 and two were observed in the Middle Sandhills near Empress June 24. This ground squirrel appears to be quite scarce in southern Alberta.

вовсат: This species appears to be thinly distributed throughout the Milk River valley, primarily in badland sections. Tracks were noted frequently, while one was heard screaming in midsummer.

RED FOX: This species appeared to be quite scarce in the Milk River valley. Only an occasional set of tracks were noted, while one was seen near Aden in cultivated fields.

WOLVERINE: Two sets of tracks were seen high in the Carthew pass area of Waterton Lakes National Park on July 28. Apparently wolverines are still present in this region of the Rocky Mountains, but in small numbers.

\section{REPTILE}

SHORT-HORNED LIZARD: One was found on the edge of the Milk River valley on May 1. Despite intensive searching, no other sites were found. During late June and early July, as many as 8 individuals of various sizes were found at this one site. Besides being very locally distributed, indiscriminate collecting appears to have contributed to the scarcity of Short-horned Lizards.

\section{SPIDER}

NORTHERN WIDOW SPIDER: On July 2, One female was found in the mouth of an old Coyote burrow along the Lost River. This species has the typical red hour-glass shaped pattern on the lower abdomen, and appears very similar to the closely related Black Widow Spider. 